\title{
Література:
}

1. Закон України «Про вищу освіту» URL: https://zakon.rada.gov.ua/ laws/show/1556-18\#Text (дата звернення 03.12.2021)

2. Максименко С.Д., Соловієнко В.О Загальна психологія. - К.: МАУП, 2001.

DOI https://doi.org/10.30525/978-9934-26-173-2-4

\section{ПРОЕКТУВАННЯ ЯК НОВІТНІЙ ПІДХІД У СФЕРІ ОСВІТИ}

\section{Дорошенко В. C.}

кандидат історичних наук, доктор наук з державного управління, доцент кафедри філології та перекладу

Київський національний університет технологій та дизайну м. Київ, Украӥна

\section{Кетова Т. М.}

старша викладачка кафедри філологї та перекладу

Київський наиіональний університет технологій та дизайну

м. Київ, Україна

Досвід майбутньотворення та конструювання в сучасній цивілізації засвідчив, що здійснення актів переходу від теорії до практики, від минулого до майбутнього, від потенційного до актуального, від природного до штучного потребують діяльності особливого типу. Такою діяльністю і виявляється проектування та його головне концептуальне завдання - проект. Невипадково проектування нині набуває інтегрального статусу та починає конкурувати з традиційними засобами пізнання та дії, посуваючи навіть теорію як головну форму організації наукового знання [1, с. 6-7] «...Сучасна наука, - пише з цього приводу Гастон Башляр,-- базується на проекті. У науковому мисленні міркування суб'єкта про об'єкт завжди приймає форму проекту».

Проектування стає найважливішою характеристикою інженерної, соціологічної та художньої свідомості, основним змістом дизайну, організації матеріального середовища людини. Висуваються навіть ідеї про проективний стан культури в цілому (К. Кантор, Н. Сидоренко та ін.), про здійсненність у проектній мові найвизначніших задумів цивілізації як такої. 
Актуалізація завдань проектування дійсно пов'язана зі станом сучасної цивілізації, яка маніфестує зростання соціальної небезпеки помилки. I тому затверджує необхідність проектного випробування усього нового, оволодіння мистецтвом проектування як перспективою реалізації образу майбутнього має принципово важливе методологічне значення для окреслення обрисів інноваційної школи, яка спрямовує своє зусилля на плекання людини як творця і проектувальника життя, господаря власної долі. Що ж актуалізує проблему проектування, створення образів майбутнього для інноваційних перетворень?

Масштаб нових історичних завдань владно диктує необхідність кардинальних змін у змістових, технологічних, управлінських складових розвитку освіти, яка покликана допомогти молодій людині оволодіти життєвою компетентністю, освоїти ситуацію соціальних і духовних змін.

Саме через освіту ми повинні підготувати людину, здатну творити i сприймати зміни, нововведення. Йдеться про зміни технологій, інформацій, знань, обставин життя. Але для того, щоб готувати людину і суспільство до інноваційного типу життя, необхідно реформувати освіту, зробити ii інноваційною за характером. Зміни вимагають конкурентоспроможності, професійної та соціальної стабільності, неперервної освіти й духовного самовдосконалення.

Світ вступив у такий етап історичного розвитку, однією із характерних рис якого є зміни, що докорінно відрізняються від тих, що були у минулому.

Змінам властиві три особливості. Вони неперервні, стійкі, стрімкі й характеризуються тенденцією до прискорення, стосуються всієї планети i майже всіх сфер діяльності людини і суспільства. Змінюється все: характер праці, яка все більше стає інтелектуальною; їі структура, умови i вимоги, які вона пред'являє до рівня знань і кваліфікації свого головного учасника - людини, яка працює в умовах неперервних змін і нововведень. Світова історія, - пише український філософ С. Б. Кримський, - дедалі більше набуває рис вихору науково-технічного прогресу, нашестя науково-технічних змін. Із незвичним розмахом наростає швидкість історичних подій, прискорюється темп світової історії. Менше ніж за 60 років було отримано 80\% знань, якими володіє людство сьогодні. Якщо з 1899 р. обсяг знань подвоювався кожні 50 років, а 31950 р. - кожні 10 років, то тепер він зростає удвічі що п’ять років [2, с. 268].

Водночас секрет зростання і розвитку,- зазначає Майкл Фуллан у книзі «Сили змін», - полягає у тому, щоб навчитися, як поводитись із силами змін, використовуючи переваги позитивних і послаблюючи вплив негативних. Майбутнє світу - у навчанні [3, с. 11]. М. Фуллан 
обгрунтовує місце і роль освіти в усвідомленні філософії змін. Місія освіти полягає у тому, щоб змінити життя учнів і допомогти виховати громадян, які можуть жити і продуктивно працювати у суспільстві, яке стає дедалі динамічнішим і складнішим. Школа має допомогти молодим людям обрати життєві орієнтири, усвідомити сутність і перспективу багатокультурних, глобальних змін, освоїти їх і здійснювати протягом усього життя. За цих умов, - зазначає М. Фуллан, - освітяни повинні розглядати себе як експертів із динаміки змін, такими їх має сприймати суспільство. Щоб стати експертом із динаміки змін, освітяни мають стати вмілими носіями змін [3, с. 23]. Головні положення філософії змін М. Фуллана:

Перше. Робота вчителів тепер складніша, аніж будь-коли. Вони повинні не відставати від швидкозмінних технологій на робочому місці [3, c. 24].

Друге. Зміни мають зосереджуватися у всіх інституціях та їх взаємодії, але освіта має особливе покликання налагодити взаємодію між ними [3, с. 27].

Третє. Вчитися - означає не отримувати більше інформації, а збільшувати здатність досягати тих результатів, які нам потрібні у житті Це генеративне навчання упродовж усього життя [3, с. 40-53].

Четверте. Головна мета освіти - досягти того, щоб якомога більше учнів навчити залучати до освіти для розуміння, що означає оволодіння основними ідеями, принципами, вміннями, достатніми для застосування їх з метою осмислення нових проблем і ситуацій, визначення шляхів розширення компетентності та способів оволодіння новими вміннями $\mathrm{i}$ знаннями $[3$, с. 80,82$]$.

П'яте. Кожен є носієм змін. Важливо бачити у проблемі джерело творчого розв'язання, цінувати індивідуальність і колективізм, особисті чинники змін як корінь змін системи [3, с. 81].

У міру глобалізації цих процесів та пов'язаного з ними переходу до наукового-інформаційних технологій відбувається зміна парадигми людського прогресу. Його сутністю, основним виміром і водночас основним важелем стає розвиток особистості, власне людський розвиток. Саме ця обставина буде визначати конкурентоспроможність кожної країни. Освітня політика, відображаючи загальнонаціональні інтереси, враховує разом з тим загальні тенденції світового розвитку, що зумовлюють необхідність суттєвих змін у системі освіти:

- прискорення темпів розвитку суспільства, розширення вибору, що викликає необхідність підвищення рівня готовності громадян до нього;

- перехід до постіндустріального, інформаційного суспільства, значне розширення міжкультурної взаємодії, у зв'язку з чим особливої 
ваги набувають комунікативна i полікультурна компетентність, культура і толерантність;

- виникнення і зростання глобальних проблем, які можуть бути розв'язані лише у рамках міжнародного співробітництва, що вимагає формування сучасного мислення у молодого покоління;

- динамічний розвиток економіки, зростання конкуренції, скорочення сфери некваліфікованої праці, глибокі структурні зміни у сфері зайнятості, визначають постійну потребу у підвищенні професійної компетентності;

- зростання ролі людського капіталу, який у розвинених країнах складає 70-80\% національного багатства, що зумовлює інтенсивний випереджувальний розвиток освіти як молоді, так і дорослого населення.

На реформування освіти істотно впливає глобальна інформаційна революція, важливим складовими якої є:

- перетворення інформації у найважливішу економічну категорію;

- всезагальний характер інформатизації суспільства, її проникнення у всі сфери життя і діяльності людини;

- освіта перестає бути єдиним джерелом знань;

- посилення «цифровізації» техносфери суспільства, активне поширення цифрових технологій за межі інформаційної сфери;

- глобалізація інформаційного середовища світового співтовариства на основі розвитку зв'язку, телебачення й телекомунікаційних мереж;

- безпрецедентне посилення інтелектуальних, творчих здібностей людини в результаті використання засобів інформатики і нових IT;

- формування нового інформаційного світорозуміння і світогляду, які суттєво змінять сучасну картину світу, парадигму й методологію освіти.

Глобалізація інфосфери має важливі психологічні, соціальні, економічні й культурологічні наслідки. Сучасна людина має реальну можливість оперативно отримувати необхідну інформацію із різних куточків світу. Вперше за всю історію розвитку цивілізації людина отримала високоефективний і доволі доступний засіб для посилення свого інтелекту і творчих здібностей.

\section{Література:}

1. Метод проектів: традиції, перспективи, життєві результати: Практико-орієнтований збірник // За наук. ред. І.Г. Срмакова. - К., 2003.

2. Крымский С.Б. Философия как путь человечности и надежды. К. : Курск, 2000.

3. Фуллан М. Сили змін: вимірювання глибини освітніх реформ. Львів : Літопис, 2000. 
4. Українське суспільство на порозі третього тисячоліття. - К., 1999.

5. Марчук Е. Украина: новая парадигма прогресса. - К. : Аваллон, 2001.

6. Стереотипы и динамика мышления. - Минск, 1993.

7. Князева Е.Н. Трансдисциплинарные комплексы знаний: синергетическая мудрость и образование // Полигнозис. - 2001. - № 2.

8. Сингх Раджа Рой. Образование в условиях меняющегося мира // Перспективы. Вопросы образования. - 1993. - № 1.

9. Тоффлер Э. Шок будущего. - М. : ООО «Издательство АСТ», 2002.

DOI https://doi.org/10.30525/978-9934-26-173-2-5

\title{
SOCIAL TRANSITIVITY AS A FACTOR IN THE FORMATION OF THE VALUE STRUCTURE OF A PERSON IN THE PROCESS OF STUDYING AT A UNIVERSITY
}

\author{
Kaimanova Y. V. \\ Senior Lecturer of Psychological Department \\ Donetsk Institute Private Joint-Stock Company "Higher Educational \\ Institution" Interregional Academy of Human Resources Management \\ Kramatorsk, Ukraine \\ Riabokon N. S. \\ Senior Lecturer of Psychological Department \\ Donetsk Institute Private Joint-Stock Company "Higher Educational \\ Institution" Interregional Academy of Human Resources Management \\ Kramatorsk, Ukraine
}

The formation of a normative-value structure is traditionally regarded as one of the most important results of the socialization of an individual. Values seem to be an obvious manifestation of the intersection of the regulation of human actions and the environment. Values are formed under the influence of social experience assimilated by a person and they are manifested in the goals, ideas, convictions of the personality itself and set the vector for the development of the personality and the content side of its activity, determining the general approach of a person to himself, to other people and to the world as a whole, giving meaning and direction to his behavior and activities. The general concept of «value» characterizes such concepts as social and personal 